\title{
GAMBARAN PSYCHOLOGICAL WELL-BEING PADA PRIA PENSIUNAN PEGAWAI NEGERI SIPIL STRUKTURAL YANG MENJADI TULANG PUNGGUNG KELUARGA
}

\author{
Ritma Trisusanti dan Satiningsih \\ Program Studi Psikologi Universitas Negeri Surabaya \\ e-mail:saty_nov@yahoo.com
}

\begin{abstract}
The purpose of this study was to reveal psychological well-being of structural civil servants who have retired and become the backbone of their families. This study used a qualitative research approach with a phenomenological method. The subjects involved in this study were two retired structural civil public servants who are male at age 59 and have different latest job rank and position. The results of this study indicated that both subjects have positive psychological wellbeing, with each dynamic that not differ too much from each other. There are several factors that influence their psychological well-being conditions, namely adequate financial source, the existence of productive or social activities carried out after the retirement and the religiousity factors.
\end{abstract}

Keywords : Psychological well-being, retirement, civil public servant.

\begin{abstract}
Abstrak: Penelitian ini bertujuan untuk mencari tahu gambaran psychological well-being pria pensiunan Pegawai Negeri Sipil struktural yang menjadi tulang punggung keluarga. Penelitian ini menggunakan pendekatan penelitian kualitatif dengan tipe penelitian fenomenologis. Partisipan yang terlibat dalam penelitian ini adalah dua orang pria pensiunan Pegawai Negeri Sipil struktural yang berusia tidak lebih dari 59 tahun yang memiliki pangkat dan jabatan terakhir yang berbeda. Teknik analisis data dilakukan dengan beberapa cara, antara lain organisasi data, koding dan analisis, serta analisis intra kasus dan analisis lintas kasus. Hasil penelitian ini menunjukkan bahwa kedua partisipan memiliki kondisi psychological well-being yang baik, dengan dinamika yang tidak berbeda jauh satu sama lain. Terdapat beberapa faktor yang berperan dalam kondisi psychological well-being kedua partisipan tersebut, antara lain sumber finansial yang memadai, adanya kegiatan produktif atau sosial yang dilakukan setelah pensiun dan faktor religiusitas.
\end{abstract}

Kata kunci : Psychological well-being, Pensiun, Pegawai Negeri Sipil.

Bekerja atau memiliki karir merupakan hal yang penting bagi kesejahteraan individu. Karir bukan hanya suatu sarana untuk bertahan hidup namun juga berguna untuk pemenuhan kebutuhan psikologis. Menurut Maslow (dalam Eliana, 2003), kebutuhan manusia secara garis besar dapat dibagi atas kebutuhan fisiologis, kebutuhan rasa aman, kebutuhan dimiliki, kebutuhan harga diri, dan aktualisasi diri. Alasan seseorang bekerja adalah bisa memenuhi salah satu kebutuhan yang diutarakan oleh Abraham Maslow tersebut. Namun, setiap orang yang bekerja dan berkarir pada suatu saat nanti pasti akan tiba pada ujung akhirnya. Akhir masa karir atau bekerja ini disebut masa pensiun.
Parnes dan Nessel (dalam Eliana, 2003) mengatakan bahwa pensiun adalah suatu kondisi dimana individu tersebut telah berhenti bekerja pada suatu pekerjaan yang biasa dilakukan. Batasan yang lebih jelas disampaikan oleh Corsini (dalam Eliana, 2003) yang mengatakan bahwa pensiun adalah proses pemisahan seorang individu dari pekerjaannya. Sedangkan berdasarkan pandangan psikologi perkembangan, pensiun dapat dijelaskan sebagai suatu masa transisi ke pola hidup baru, ataupun merupakan akhir pola hidup (Schwarz dalam Hurlock, 1983). Transisi ini meliputi perubahan peran dalam lingkungan sosial, perubahan minat, nilai, dan perubahan dalam segenap aspek kehidupan 
seseorang. Jadi seseorang yang memasuki masa pensiun bisa mengubah arah hidupnya dengan mengerjakan aktivitas lain, tetapi bisa juga tidak mengerjakan aktivitas tertentu lagi.

Masa pensiun menurut Turner dan Helms (dalam Anggi, 2004) terjadi ketika individu berhenti dari dunia kerja dan mulai menjalankan peran baru dalam kehidupannya. Salah satu hal yang menjadi sebab individu dipensiunkan adalah faktor usia, yaitu di usia dimana seseorang dianggap kurang produktif. Menurut teori perkembangan, individu baru memasuki masa pensiun ketika usianya berada pada kategori transisi ke dewasa akhir atau lanjut usia (60 tahun dan lebih). Oleh karena itu, masa pensiun sejauh ini dianggap sebagai tugas perkembangan lanjut usia dan merupakan tahapan terakhir dalam siklus pekerjaan individu. Produktivitas kerja individu yang berusia lanjut dianggap sudah menurun dan oleh karena itu harus dipensiunkan untuk dapat melanjutkan kehidupan yang terbebas dari aktivitas kerja.

Menurut Anggi (2004), seseorang yang baru melalui masa pensiun sangat rentan terhadap permasalahan psikologis, terutama muncul bila ia tidak berhasil menemukan jalan keluar masalah yang timbul sebagai akibat dari proses transisi. Ia juga menambahkan bahwa orang yang mengalami problem saat pensiun biasanya justru mereka yang pada dasarnya sudah memiliki kondisi mental yang tidak stabil, konsep diri yang negatif, dan rasa kurang percaya diri terutama berkaitan dengan kompetensi diri dan keuangan atau penghasilan. Selain itu, masalah harga diri memang sering menjadi akar depresi pada masa pensiun karena orangorang dengan harga diri yang rendah semasa produktifnya cenderung akan menjadi overachiever semata-mata untuk membuktikan dirinya sehingga mereka bekerja habis-habisan sampai mengabaikan sosialisasi dengan sesamanya. Pada orang dengan kejiwaan yang stabil, konsep diri positif, rasa percaya diri yang kuat serta didukung dengan keuangan yang cukup, orang tersebut akan lebih dapat menyesuaikan diri dengan kondisi pensiun karena selama bertahun-tahun ia bekerja, ia "menabung" pengalaman, keahlian serta keuangan untuk menghadapi masa pensiun.

Kehidupan masa pensiun menurut Moen (dalam Anggi, 2004) terkait dengan perasaan sejahtera (well-being) yang dialami individu. Ia menuturkan bahwa bagi kebanyakan orang lanjut usia, pensiun dari pekerjaan mereka merupakan sebuah kejadian yang penting, sebuah jalan lintasan yang menandai seseorang masuk ke dalam tahapan akhir masa dewasa. Hal ini bukan hanya sebuah masa transisi objektif, tapi juga merupakan sebuah perkembangan subjektif dan transformasi sosial-psikologis yang berhubungan dengan keadaan fisik dan psychological well-being. Turner \& Helms (dalam Anggi, 2004) mengatakan bahwa individu yang merasa masih mampu untuk bekerja tetapi sudah memasuki masa pensiun, seringkali kurang termotivasi untuk membuat penyesuaian yang baik terhadap masa pensiun yang pada akhirnya akan memengaruhi keadaan fisik maupun psikologis. Pengaruh pada aspek psikologis ini merujuk pada aspek psychological well-being.

Psychological well-being merupakan sebuah konstruksi dalam psikologi yang dirumuskan oleh Carol D. Ryff yang berarti kemampuan individu dalam menerima dirinya apa adanya, membentuk hubungan yang hangat dengan orang lain, mandiri terhadap tekanan sosial, mengontrol lingkungan eksternal, memiliki arti dalam hidup serta merealisasikan potensi dirinya secara kontinyu (Ryff \& Keyes, 1995). Psychological well-being terdiri dari enam dimensi yang mengungkapkan fungsi psikologis yang positif setiap individu, yaitu dimensi kemampuan individu dalam menerima diri apa adanya (self acceptance), 
membina hubungan yang positif dengan orang lain (positive relation with others), otonomi (autonomy), penguasaan lingkungan (enviromental mastery), mampu merumuskan tujuan hidup (purpose in life), dan mampu menumbuhkan serta mengembangkan potensi pribadi (personal growth).

Konsekuensi negatif dan positif saat menjalani masa pensiun telah banyak diteliti. Kim \&Moen (dalam Eliana, 2003) menemukan bahwa masa pensiun dapat meningkatkan sense of well-being dari individu jika ia mempersepsinya sebagai keluar dari keadaan yang menekan dari pekerjaannya. Tetapi di sisi lain, pensiun juga dapat mengurangi tingkat kesejahteraan bagi individu karena mereka kehilangan kelekatan yang mereka dapatkan dalam pekerjaan mereka, kehilangan jaringan sosial dan identitas mereka. Kehilangan pekerjaan, jabatan, fasilitas, penghargaan dan lingkungan pergaulan yang sudah diakrabi selama bertahun-tahun dapat menjadi suatu pukulan berat bagi individu yang memasuki masa pensiun (Sutarto \& Ismulcokro, 2008). Fase akhir karir mereka akan menjadi suatu tekanan yang sangat memukul dan menggoncang jika mereka tidak memiliki kesiapan-kesiapan tertentu, baik secara materi ataupun kesiapan psikologis.

Sehubungan dengan usia pensiun, terdapat sebuah penelitian yang dilakukan untuk menginvestigasi efek pensiun pada psychological well-being yang dilakukan di Kanada dengan menggunakan individu dalam kelompok usia 45-54 tahun dan kelompok usia 55 tahun ke atas. Hasil penelitian ini menunjukkan bahwa pada kelompok usia 4554 tahun, masa pensiun tidak memiliki pengaruh yang signifikan, sementara pada individu kelompok usia 55 tahun ke atas, masa pensiun memiliki efek positif yang signifikan pada psychological well-being mereka (Latief, 2010).

Penelitian lain (Karp dalam Hendry \&
Kloep, 2002) juga dilakukan dengan mewawancarai 72 orang yang bekerja pada usia lima puluhan. Mereka dimintai pendapat mengenai pekerjaan dan sikap mereka terhadap pensiun. Jawaban responden tersebut terbagi menjadi tiga kelompok: (1) mereka yang sangat melekat dengan pekerjaannya sehingga tidak ingin membayangkan masa pensiun; (2) mereka yang melihat masa pensiun sebagai kesempatan untuk melakukan hal-hal yang selama ini tidak sempat dikerjakan; (3) mereka yang mempunyai perasaan bercampur atau sama sekali belum memikirkan tentang masa pensiun. Pada umumnya, mereka yang memiliki kesehatan yang prima atau mereka yang sangat menyukai pekerjaannya, akan berusaha mencapai tujuan karir mereka dan mereka yang merasa khawatir akan masalah keuangan memiliki sikap yang negatif terhadap pensiun.

Beberapa penelitian di atas menunjukkan bahwa masa pensiun tidak memiliki dampak yang konsisten pada setiap orang. Beberapa faktor seperti usia ketika pensiun, kesukaan pada pekerjaan, dan rencana hidup setelah pensiun berpengaruh terhadap positif atau negatifnya masa pensiun.

Penelitian ini bertujuan untuk mengetahui psychological well-being pada Pegawai Negeri Sipil (PNS) yang bekerja di bagian struktural. Masa pensiun mereka sebagai Pegawai Negeri Sipil struktural adalah pada usia 56 tahun, seperti yang tercantum dalam Peraturan Pemerintah (PP) Nomor 32 Tahun 1979 tentang Pemberhentian PNS, bahwa Batas Usia Pensiun (BUP) Pegawai Negeri Sipil (PNS) Struktural yaitu 56 (lima puluh enam) tahun. Secara psikologis, usia 56 tahun termasuk dalam kategori dewasa menengah atau dewasa madya. Menurut Santrock (2002), usia dewasa tengah (middle adulthood) adalah periode perkembangan yang dimulai kira-kira pada usia 35-45 tahun hingga memasuki usia 
60. Dalam fase ini mereka masih cukup produktif dan belum dapat digolongkan manula. Mereka yang berada dalam rentang usia ini pada umumnya masih memiliki kemampuan untuk bekerja. Karena itu, batas usia pensiun yang ditetapkan oleh pemerintah untuk PNS struktural dapat diasumsikan akan menimbulkan konsekuensi psikologis tertentu. Satu sisi mereka masih mampu bekerja, namun di sisi lain mereka terpaksa harus berhenti. Konsekuensi psikologis yang dirasakan akan terlihat pada penyesuaian dirinya ketika mengalami masa pensiun.

Pertanyaan yang muncul kemudian adalah bagaimana sebenarnya para pensiunan PNS struktural ini memandang diri mereka sendiri setelah pensiun? Bagaimana penyesuaian diri mereka dengan kehidupan baru dimana mereka tidak lagi berada dalam lingkungan seperti saat dulu bekerja? Apakah mereka mampu memandang diri mereka secara positif dengan segala perubahan yang terjadi setelah pensiun? Bagaimana hubungan mereka dengan orang-orang di sekitar mereka sehubungan dengan cara mereka memandang diri mereka setelah pensiun? Semua pertanyaan tersebut akan mengungkap persoalan tentang kesejahteraan psikologis pensiunan PNS struktural. Penelitian ini berusaha mengksplorasi bagaimana kondisi psychological well-being pada pensiunan Pegawai Negeri Sipil struktural.

Selain batasan usia PNS struktural, peneliti juga tertarik untuk fokus pada sampel pria yang menjadi tulang punggung keluarga. Hal ini dikarenakan adanya paham gender tradisional yang masih umum di kalangan masyarakat Indonesia yang lebih menuntut pria untuk bekerja di luar rumah demi memenuhi kebutuhan keluarganya. Kondisi demikian akan membuat masa pensiun mereka juga akan berpengaruh terhadap kondisi keluarga dan pada akhirnya juga akan berpengaruh balik terhadap kesejahteraan psikologis para pensiunan tersebut.

\section{METODE}

Penelitian ini menggunakan pendekatan kualitatif dengan metode studi kasus. Metode studi kasus dipilih karena penelitian ini dimaksudkan untuk memahami fenomena apa yang dialami oleh subjek penelitian dalam perilaku, persepsi, motivasi, tindakan, dan lain-lain, secara holistik pada suatu konteks khusus yang alamiah (Moelong, 2006). Unit analisis dalam penelitian ini adalah psychological well-being pensiunan Pegawai Negeri Sipil struktural. Studi kasus yang dipilih adalah studi kasus intrinsik karena peneliti bertujuan untuk memahami secara utuh kasus yang diteliti tanpa harus dimaksudkan untuk menghasilkan konsepkonsep atau teori ataupun tanpa upaya menggeneralisir (Poerwandari, 2005).

\section{Partisipan}

Partisipan penelitian direkrut melalui teknik purposive sampling. Teknik ini digunakan karena partisipan penelitian ditentukan berdasarkan kriteria yang ditetapkan peneliti berdasarkan fokus penelitian dan hasil penelusuran literatur. Dua pria pensiunan Pegawai Negeri Sipil (PNS) Dinas Pendidikan Kecamatan Waru, Sidoarjo berusia 59 tahun menjadi partisipan penelitian ini. Keduanya saat ini masih menjadi tulang punggung keluarga. Sebagai PNS struktural yang sudah berusia lebih dari 56 tahun mereka sudah harus pensiun, meskipun usia tersebut belum bisa dikatakan manula. Pada usia tersebut mereka masih cukup mampu untuk bekerja. Jika mereka sudah pensiun padahal masih diandalkan oleh keluarganya untuk memenuhi kebutuhan hidup, maka ada kemungkinan besar akan berpengaruh pada kesejahteraan diri si pensiunan. Kedua partisipan tersebut juga dipilih karena mereka tidak memiliki karir lain setelah mereka memasuki masa pensiun. 


\section{Teknik Pengumpulan Data}

Pengumpulan data dalam penelitian ini menggunakan teknik wawancara mendalam dengan pedoman umum. Wawancara adalah percakapan dengan maksud tertentu. Percakapan dilakukan oleh dua pihak, yaitu pewawancara (interviewer) yang mengajukan pertanyaan dan terwawancara (interviewee) yang memberikan jawaban atas pertanyaan itu (Moleong, 2006). Dalam proses wawancara ini peneliti dilengkapi pedoman wawancara yang sangat umum, yang mencantumkan isuisu yang harus digali tanpa menentukan urutan pertanyaan, bahkan mungkin tanpa bentuk pertanyaan eskplisit (Poerwandari, 2001). Pedoman ini tetap memungkinkan peneliti untuk mengikuti minat partisipan dan pada saat yang sama tetap menjaga alur wawancara agar tidak keluar dari fokus penelitian. Pedoman wawancara dibuat berdasarkan kajian atas literatur tentang kesejahteraan psikologis (psychological well-being).

\section{TeknikAnalisis Data}

Data hasil penelitian dianalisis dengan tahapan organisasi, koding, dan analisis. Dalam melakukan organisasi data, peneliti mula-mula mengumpulkan semua data yang telah didapatkan, mentranskripsinya dalam bentuk verbatim, dan memberikan kode berkas tersendiri untuk masing-masing partisipan. Peneliti melakukan koding dengan cara membaca transkrip berulang-ulang untuk mendapatkan fakta-fakta dan menemukan tema-tema yang muncul dalam wawancara. Peneliti kemudian menggunakan satu bagian kosong untuk menuliskan pemadatan fakta, tema, maupun kata kunci yang dapat menangkap esensi data dari teks yang dibaca (Poerwandari, 2001). Secara bersamaan, peneliti juga menuliskan refleksi pikiranpikiran dan ide-ide sementara yang muncul. Setelah selesai, peneliti membuat daftar tema yang muncul dan mencoba memikirkan hubungan tema tersebut. Kemudian data-data yang telah ditandai tersebut dikelompokkan berdasarkan kesamaan karakteristik tiap tema.

Adapun analisis yang digunakan dalam penelitian ini adalah analisis penjodohan pola (pattern matching), dimana peneliti menentukan tema-tema penelitian dan kemudian memasukkannya ke dalam kategori-kategori tertentu, lalu memaparkan data-data temuan peneliti dalam bentuk narasi. Selanjutnya ada dua macam proses analisis yang biasa dilakukan dalam menganalisis hasil penelitian, yaitu dilakukan secara intra-kasus dan antar-kasus (Riawaty, 2006). Pada penelitian ini lebih diutamakan kedalaman sehingga analisis intra-kasus atau kasus demi kasus dilakukan terlebih dahulu. Langkah berikutnya adalah melakukan analisis antar kasus dengan cara membandingkan kasus-kasus yang telah dianalisis dalam analisis lintas kasus dan menganalisanya dengan menggunakan teoriteori yang berhubungan dalam penelitian. Dimensi-dimensi Psychological well-being sebagaimana dijelaskan oleh Riff (Ryff \& Keyes, 1995) dijadikan panduan oleh peneliti dalam membuat analisis dan interpretasi. Dimensi-dimensi tersebut adalah penerimaan diri (self-acceptance), hubungan positif dengan orang lain (positive relation with others), otonomi (autonomy), penguasaan lingkungan (enviromental mastery), tujuan hidup (purpose in life) dan pengembangan potensi pribadi (personal growth).

\section{HASIL PENELITIAN}

\section{Partisipan 1}

Penerimaan Diri. Bagi subjek, masa pensiun bukanlah suatu hal yang menjadi penghalang berarti baginya untuk melanjutkan hidup. Baginya pensiun 
hanyalah sebuah status dan batasan kedinasan, bukan sesuatu yang akan menghentikan langkahnya untuk menjadi manusia yang produktif dan berusaha untuk keluarganya dan dirinya sendiri. Subjek juga menganggap bahwa bekerja merupakan salah satu bentuk ibadah yang ia lakukan sebagai bagian dari hidup.

Namanya hidup itu tidak dibatasi oleh masa pensiun. Pensiun itu kan hanya batasan kedinasan saja [...]. Adapun yang namanya, namanya manusia itu, itu kan punya, punya, apa namanya itu, nilai, dorongan untuk mempertahankan hidup ya baik dunia maupun di akhirat. Khususnya di dunia itu, walaupun pensiun, kalau memang masih bisa berusaha ya berusaha $[\ldots]$.

Subjek menuturkan bahwa ia cukup mampu melakukan penyesuaian diri dengan masa pensiunnya. Ia mengatakan bahwa tidak ada kecemasan-kecemasan tertentu yang muncul sebelum pensiun maupun sesudah pensiun. Kalaupun ada sesuatu yang dirasakan berbeda, ia berpendapat bahwa hal itu hanyalah sebuah proses adaptasi saja. Satu-satunya kecemasan yang muncul setelah pensiun hanyalah masalah finansial.

\begin{abstract}
Yang berbeda itu memang masalah ekonomi tentunya ya. Kalau masih dinas itu kan memang gampang cari ya. Ya itu memang terasa setelah pensiun. Karena ada berkurangnya pemasukan itu, ya kerasa. Tapi dari saya, bukan masalah. Kalau jadi masalah ndak ada habisnya. Karena memang semuanya itu sudah takdir. Kita syukuri saja.
\end{abstract}

Subjek menyandarkan diri pada Tuhan untuk menghadapi kecemasan itu dan berusaha untuk mensyukuri masa pensiunnya.

Hubungan Positifdengan Orang Lain. Masa pensiun ini, bagi subjek, bukanlah suatu halangan untuk tetap berkegiatan dan menjalin hubungan baik dengan orang-orang di sekitarnya. Ia tergabung dalam beberapa kelompok yang berkecimpung dalam kegiatan spiritual, antara lain kelompok pengajian yang ia ikuti sejak ia belum menjadi PNS. Ia juga menjadi pengurus yayasan kelompok bimbingan ibadah haji.

Jadi kumpul untuk istilahnya, sharing,
komunikasi, diskusi, mempelajari dari pada yaa
alam sekitar ini dari sisi ketuhanan. Terus saya
juga mengikuti, membantu yayasan kelompok
bimbingan ibadah haji yang terbesar di
Sidoarjo.

Otonomi. Subjek banyak mengambil keputusan-keputusan bagi keluarga dengan baik terutama yang berhubungan dengan perencanaan keuangan sebagai persiapan menjelang masa pensiun. Ia tidak memiliki sosok tertentu yang paling ia percaya dalam mengambil keputusan. Subjek selalu menyandarkan semua permasalahan dan keputusan kepada Tuhan.

Ya ndak ada. Semua saya anggap baik, baik. Sekarang ada masalah yang, tapi kalau saya itu selalu bersandar pada Yang Kuasa itu. Jadi apapun permasalahan itu, disandarkan pada Yang Kuasa. Kita itu kan ada yang menciptakan. Apa itu namanya alam itu kan, alam itu kan juga Tuhan yang menciptakan.

Penguasaan Lingkungan. Setelah pensiun, subjek tidak memiliki kendala apapun yang berhubungan dengan kecemasan atau hal-hal yang berhubungan dengan kondisi psikologisnya.

\footnotetext{
Jadi suasana seperti sebelum pensiun itu ya memang sekarang ini jauh sekali. Sekarang bergaul dengan orang-orang di sekitar sini, sama orang-orang dari pengajian. Memperdalam ilmu akidah, ilmu tasawuf, sama-sama orang banyak, teman-teman.
}

Walaupun ia menyadari bahwa lingkungannya yang sekarang dengan lingkungan sebelum ia pensiun memang jauh berbeda. Subjek merasa nyaman dan puas dengan lingkungannya yang sekarang. Tapi ia berusaha untuk selalu bersyukur dan menikmatinya. 
Tujuan Hidup. Makna hidup bagi subjek MC adalah untuk mencari bekal untuk kehidupan selanjutnya karena kehidupan di dunia ini tidak kekal dan akan berlanjut ke kehidupan berikutnya.

Tujuan hidup ini gak lain adalah sebagaimana apa yang dikatakan Nabi itu, secerdas-cerdasnya manusia itu adalah yang mau mengoreksi dirinya sendiri atas segala kekurangannya dan beramal untuk kehidupan yang lebih kekal lagi. Jadi kita itu, hidup itu tidak hanya sekali di dunia, tapi berlanjut setelah tutupnya dunia, ada kehidupan yang lebih kekal.

Pertumbuhan Pribadi. Subjek merasakan adanya perubahan dalam dirinya sejak memasuki masa pensiun. Beberapa diantaranya adalah banyaknya waktu luang yang dapat ia gunakan untuk memperdalam wawasan agama dalam rangka mendekatkan diri pada Tuhan.

Sekarang jadi punya banyak waktu untuk membaca. Untuk membaca untuk belajar. Jadi dulu gak sempat baca, bacanya sebentar aja di kantor, karena memang sibuk, sekarang banyak waktu saya gunakan untuk membaca. Bacabaca buku agama.

\section{Partisipan 2}

Penerimaan Diri. Bagi subjek yang merasa atau menganggap dirinya hanyalah pegawai "rendahan" ini, masa pensiun merupakan masa dimana ia akhirnya terbebas dari beban pekerjaan. Ia merasa lebih bahagia dan memiliki banyak waktu untuk mendekatkan diri dengan keluarga dan melakukan hal-hal yang ia inginkan. Ia merasa sangat bersyukur bahwa ia tetap mendapatkan gaji meskipun sudah tidak lagi bekerja.

Ya kalau masa pensiun kita, kita bersyukurlah, kita tidak kerja, tapi mendapatkan gaji-lah setidaknya itu. Malah apa ya tambah senang karena kita ngumpul tiap hari. Terus di rumah kan ada hiburan eh putu-putu [cucu-cucu]."
Hubungan Positif dengan Orang Lain. Subjek juga menuturkan bahwa hubungannya dengan mantan rekan kerjanya masih baikbaik saja sampai saat ini. Ia masih sering mengunjungi mantan rekan kerjanya di kantor. Ia juga masih sering dipanggil oleh mantan rekan kerjanya untuk mengerjakan hal-hal tertentu.

Ya menurut saya ndak, ndak ada perubahan. Kalau kita ingin eh ketemu temen-temen ya masih bisa kesana ke kantor sana. Kadangkadang kita dipanggil sama teman-teman kalau ada, kalau ada keperluan-keperluan apa gitu.

Otonomi. Subjek mengatakan bahwa pada masa pensiun ini ia justru mendapatkan kebebasan. Ia bisa memilih apa yang akan dilakukannnya setiap hari tanpa terikat lagi dengan jadwal kerja dinas.

Oh iya memang agak terikat kalau masih kerja itu. Bangunnya harus pagi [...] kalau bangun pagi itu ya gimana persiapannya untuk berangkat. Kalau sekarang ini kan santai, ndak ada yang merintah, ndak terikat apa apa.

Penguasaan Lingkungan. Saat ini subjek menjalankan beberapa usaha yang dirintisnya, antara lain usaha laundry atau jasa cuci pakaian, toko kebutuhan sehari-hari, berjualan pulsa dan jasa pembayaran rekening listrik dan telpon di kompleks rumahnya. Ia juga dipercaya menjadi ketua RT (Rukun Tetangga) di lingkungan rumahnya. Motivasinya yang paling utama adalah membantu orang-orang di lingkungannya.

\footnotetext{
Ya ada 12 tahun itu suruh gantiin ga ada yang mau hahahha soale RT itu jabatan apa sih. RT itu kan jabatan sosial, tidak mendapat gaji, jadi ya $n d a k$ ada yang mau.
}

Tujuan Hidup. Bagi subjek, tujuan hidup setelah pensiun saat ini adalah mendekatkan diri kepada Tuhan. Ia merasa bahwa ia harus mensyukuri segala hal yang telah diberikan Tuhan kepadanya agar ia tidak memikirkan segalanya terlalu berat. 
Arti hidup ya [...] kita mencari apa ya, kebahagiaan untuk hidup ini. Jangan sampai kita hidup itu dibuat berat. Ya seadanya, apa yang dikaruniakan oleh Allah baik itu materi atau apa kita terima saja. Jadi tidak terlalu berat gitu loh pikiran. Apa yang kita terima kita syukuri.

Pertumbuhan Pribadi. Setelah pensiun, subjek berpendapat bahwa hal yang berkembang pada dirinya adalah hubungannya dengan Tuhan. Ia merasa bahwa dengan umurnya yang sekarang ini ia semakin dekat dengan Tuhan.

Ya perubahan dari dulu dan sekarang ini, perubahan cuma, ke Allah saja. Kita buat ibadah utamanya. Kan tiap hari sudah dekat sama keluarga. Waktu yang luang kita buat ibadah supaya kita tenang, lebih tenang daripada dulu. Ya tidak ada beban-beban lain.

Ia semakin memanfaatkan masa pensiunnya untuk lebih mendekatkan diri kepada Tuhan dan juga punya lebih banyak waktu luang untuk untuk dihabiskan bersama keluarganya.

\section{PEMBAHASAN}

Penerimaan Diri. Penerimaan diri pada kedua subjek dilihat dari bagaimana subjek mampu bersikap positif terhadap diri sendiri dan mengakui serta menerima setiap aspek yang ada pada dirinya, baik yang bersifat baik atau buruk. Selain itu, dilihat juga bagaimana individu merasa positif dengan kehidupan masa lalunya dan kehidupannya yang sekarang (Ryff, 1998). Berdasarkan data yang diperoleh, kedua subjek cenderung memandang masa pensiun sebagai sesuatu yang positif. Baik subjek I (MC) maupun subjek II (AE), sama-sama bersikap menerima dan pasrah pada segala hal dan perubahan-perubahan yang terjadi pascapensiun. Sikap itu pada akhirnya memunculkan rasa penerimaan diri pada keadaan mereka pascapensiun. Hal ini sesuai dengan konsep integratif yang dikemukakan Erickson (dalam Santrock, 2002): "Integritas ego berarti menerima keadaan dirinya sendiri dan mensyukuri nasib".

Sesuai dengan pendapat Hurlock (2004) tentang berbagai sikap yang mungkin muncul pascapensiun, maka subjek I dan subjek II termasuk pada kategori transformer (pengalih peran), dimana orang-orang yang berada pada kategori ini cenderung bersikap mau mengubah gaya hidupnya dengan mengurangi kegiatan-kegiatan berdasarkan pilihan sendiri dengan menciptakan gaya hidup yang baru dan menyenangkan bagi, dengan cara melepaskan peran lama dan menggantinya dengan peran baru. Sikap positif itulah yang membentuk pemaknaan mereka terhadap masa pensiun dan sekaligus mengarahkan bagaimana subjek I dan II bereaksi terhadap perubahan di berbagai aspek kehidupan mereka yang terjadi setelah pensiun.

Disamping perbedaan jabatan terakhir kedua subjek tersebut, terdapat pula perbedaan mengenai bagaimana cara kedua subjek memandang pekerjaan mereka. Subjek I (MC) cenderung bangga terhadap pekerjaannya dan menyebut bahwa menjabat sebagai kepala dinas bisa dianggap sebagai salah satu kelebihan atau sesuatu yang bisa dibanggakan. Sementara subjek II (AE) yang hanya bekerja sebagai pesuruh yang merangkap sebagai staff administrasi, ia memiliki cara pandang yang sedikit negatif mengenai pekerjaannya dengan menyebut dirinya sebagai "pegawai rendahan". Perbedaan ini bisa juga dikaitkan dengan tingkat pendidikan kedua subjek tersebut. Mulyono (2011), mengatakan bahwa pendidikan berkorelasi signifikan dengan psychological well-being. Seseorang yang berpendidikan tinggi akan berpeluang lebih besar untuk memperoleh jabatan dan pendapatan yang baik serta status sosial yang lebih tinggi daripada orang yang berpendidikan lebih rendah. Individu 
berpendidikan tinggi juga akan memiliki wawasan yang lebih luas yang sekaligus dapat memberikan keuntungan intrinsik (berupa kebanggaan) bagi individu tersebut.

Mengenai kepuasan hidup saat ini, kedua subjek merasa puas dan senang dengan kehidupannya saat ini. Kedua subjek berpendapat bahwa pensiun merupakan sebuah fase hidup yang memang harus dilalui sebagai suatu bagian proses kehidupan. Mereka sama-sama mendapat dukungan dari keluarga dan tidak merasakan ada suatu perbedaan sikap dari keluarga mereka setelah pensiun.

Selain itu, ada sisi penting berkaitan dengan penerimaan diri kedua subjek mengenai masa lalu mereka, khususnya yang berhubungan dengan penerimaan diri terhadap kehidupan di masa kecil yang dibesarkan dalam keluarga dengan kondisi ekonomi yang kurang. Ryff (1989) menyatakan bahwa pengalaman hidup yang ditemui seseorang sehari-hari dan interpretasi individu terhadap pengalaman pengalaman tersebut, khususnya dalam domain-domain kehidupan yang dianggap penting, merupakan pengaruh utama dalam pertumbuhan dan perkembangan psychological well-being. Pada subjek MC dan AE, mereka sama-sama dibesarkan dalam kondisi keluarga yang kurang dalam aspek ekonomi. Berangkat dari sana, kedua subjek sama-sama menginginkan agar anak-anak mereka tidak mengalami hal yang sama dengan yang mereka alami. Oleh karena itu, selama ini mereka bekerja untuk dapat memperbaiki kondisi finansial keluarga, bahkan sebelum pensiun, yang akhirnya membuat mereka melakukan persiapan-persiapan finansial, dan setelah pensiun keinginan itu tetap mereka lanjutkan dengan konsen pada usaha-usaha yang mereka miliki.

Hubungan Positif Dengan Orang Lain. Seseorang dikatakan memiliki hubungan yang positif dengan orang lain jika menunjukkan adanya hubungan timbal balik dengan orang lain (Ryff, 1989). Kedua subjek mengaku memiliki hubungan yang baik dengan keluarga meskipun tidak terlalu dekat dengan anak-anak mereka. Oleh karena itu, kedua subjek merasa bersyukur bahwa masa pensiun memberikan mereka banyak waktu bersama keluarga. Selain di lingkungan keluarga, kedua subjek juga masih terlibat dalam berbagai kegiatan di lingkungan masyarakat. Subjek MC tergabung dalam kelompok spiritual dan ia juga menjadi pengurus yayasan haji terbesar di Sidoarjo. Sementara subjek AE masih menjabat sebagai ketua RT, dimana ia banyak terlibat dalam kegiatan-kegiatan di lingkungan rumahnya.

Kedua subjek juga menunjukkan sikap kepedulian kepada orang-orang di sekitarnya. MC menuturkan bahwa ia memang senang membantu orang yang sedang membutuhkan, itu diperkuat oleh penuturan istrinya yang mengatakan bahwa setelah pensiun subjek pernah mengutarakan niat untuk lebih banyak berbuat baik untuk orang lain. AE juga menuturkan bahwa menjadi seorang ketua RT cukup ia nikmati karena memberinya kesempatan untuk menolong orang lain. Dari paparan tersebut dapat disimpulkan bahwa pada dimensi hubungan positif dengan orang lain, kedua subjek berusaha menjaga hubungan baik dengan orang lain dengan cara tetap terlibat dalam kegiatan-kegiatan kemasyarakatan dan masa pensiun ini memberikan banyak kesempatan bagi mereka untuk melakukannya.

Otonomi. Dimensi otonomi digambarkan dari bagaimana seseorang mampu mandiri dalam menyelesaikan masalahnya sehari-hari, mampu menghadapi tekanan sosial yang dihadapi serta mampu mengevaluasi diri berdasarkan standar pribadi (Ryff, 1989). Kedua subjek mampu melepaskan diri dari tekanan sosial untuk 
bertindak. Kedua subjek mengaku lebih sering membuat keputusan sendiri mengenai hal-hal yang berhubungan dengan hidupnya, terutama masalah pengaturan finansial. Meski begitu, kedua subjek tetap mempertimbangkan pendapat orang lain di keluarganya. Subjek MC mengakui bahwa ia seringkali melibatkan istrinya, sedangkan AE lebih banyak meminta bantuan menantu ketiganya. Kedua subjek mengaku tidak memiliki masalah tertentu yang berhubungan dengan masa pensiun dalam kehidupan mereka saat ini. Mereka berusaha melakukan apa yang bisa mereka lakukan sekarang untuk mengisi waktu luang.

Penguasaan Lingkungan. Dalam dimensi penguasaan lingkungan, dapat dilihat dari bagaimana individu mampu mengontrol lingkungannya sesuai dengan kondisi psikologisnya dan mampu memanfaatkan kesempatan yang ada di lingkungan secara efektif (Ryff, 1989). Seperti yang telah dipaparkan, kedua subjek bisa dikatakan mampu berbaur di lingkungannya dengan baik karena kedua subjek tersebut masih terlibat dalam berbagai kegiatan di masyarakat. Subjek MC tergabung dalam kelompok spiritual dan ia juga menjadi pengurus yayasan haji terbesar di Sidoarjo. Sementara subjek AE masih menjabat sebagai ketua RT dimana ia banyak terlibat dalam kegiatan-kegiatan di lingkungan rumahnya. Kedua subjek merasa penting untuk melakukan berbagai kegiatan di masa pensiun. Hal ini dapat dijelaskan melalui activity theory (dalam Siegelman \& Rieder, 2006). Teori ini menjelaskan bahwa para orang dewasa lanjut akan mencapai kepuasan hidup mereka dengan menjaga gaya hidup dan aktivitas sebelumnya, apakah dengan cara melanjutkan aktivitas yang lama atau melakukan kegiatan yang baru sebagai substitusi, misalnya mengerjakan hobi sebagai pengganti kerja, bekerja secara sukarela atau mencari sesuatu yang membuat dirinya bersemangat atau bergairah (Havighusrt, Neugarten and Tobin, 1968; Fry, 1992; dalam Siegelman \& Rider, 2006). Menurut Bull \& Aucoin, Cutler, Kline (dalam Hurlock, 1994) bahwa partisipasi aktif dalam kelompok memberikan sumbangan besar terhadap kesejahteraan psikologis atau psychological well-being dan meningkatkan kepuasan hidup yang diperoleh.

Kedua subjek juga terlihat terbuka pada pengalaman-pengalaman baru yang ditawarkan kepadanya sekaligus sebagai sumber finansial. Subjek MC sempat mengikuti kelompok usaha MLM (Multi Level Marketing) walaupun akhirnya berhenti karena tidak berhasil dan kini merintis usaha tiga warung internet (warnet). Sementara subjek AE terbuka pada usaha-usaha baru yang disarankan oleh menantunya, seperti membuka jasa pembayaran rekening telepon dan listrik serta merintis usaha toko kebutuhan sehari-hari, jasa cuci baju (laundry), dan counter pulsa. Dilihat dari gambaran penguasaan lingkungan kedua subjek, mereka memiliki kemampuan penguasaan lingkungan yang baik terutama yang berhubungan dengan kehidupan di masa pensiun mereka. Mereka melibatkan diri dalam kegiatan-kegiatan kemasyarakatan dan mengatasi menurunnya pemasukan finansial dengan mengelolah usaha yang mereka rintis.

Tujuan Hidup. Dimensi tujuan hidup digambarkan sebagai sejauh mana individu memiliki tujuan hidup dan mampu mengarahkan hidupnya menuju tujuan hidup tersebut (Ryff, 1989). Semua subjek dalam penelitian ini memiliki tujuan hidup dan impian yang ingin direalisasikan dalam kehidupan saat ini. Subjek MC ingin menambah satu rumah lagi. Rumah itu nantinya akan diberikan kepada anak bungsunya sehingga masing-masing anaknya akan memiliki satu rumah. Sementara subjek 
AE ingin mengelolah dan semakin memperluas usahanya.

Kedua subjek juga memiliki pandangan yang sama mengenai tujuan hidup. Kedua subjek ingin lebih mendekatkan diri kepada Tuhan dan banyak berbuat baik sebagai bekal kehidupan mereka di akhirat. Myers (dalam Hooyer \& Roodin, 2003) mengatakan bahwa individu dewasa yang lebih tua usianya cenderung mempunyai skor yang lebih tinggi pada pengukuran well-being, khususnya jika mempunyai interaksi sosial yang memuaskan, secara keseluruhan mempunyai kesehatan yang baik dan mempunyai religiusitas yang kuat. Menurut Eddington \& Shuman (dalam Mulyono, 2011), agama berkorelasi dengan psychological well-being. Pengalaman agama memberikan pemaknaan terhadap kehidupan sehari-hari dan dukungan dalam menghadapi krisis kehidupan. Keuntungan beragama terutama lebih dirasakan oleh individu yang membutuhkan dukungan sosial seperti para pensiunan dan janda. Hal ini juga sesuai dengan apa yang diungkapkan oleh Jalaluddin (2002), bahwa pada peralihan ke usia tua, perhatian seseorang lebih tertuju pada upaya untuk menemukan ketenangan batin.

Pertumbuhan Pribadi. Dimensi pertumbuhan pribadi digambarkan sebagai suatu tendensi pengembangan potensi, untuk tumbuh dan berkembang sebagi pribadi yang ditandai dengan keterbukaan terhadap pengalaman baru dan pemikiran untuk perbaikan dan perkembangan yang berkelanjutan sepanjang hidup (Ryff, 1989). Individu dikatakan memiliki pertumbuhan pribadi yang baik apabila mereka sadar akan potensinya, memiliki perasaan untuk berkembang secara berkelanjutan, melihat kemajuan diri dan tingkah laku dari waktu ke waktu, berubah dengan cara yang efektif untuk menjadi lebih baik dan terbuka terhadap pengalaman-pengalaman baru (Ryff, 1989). Kedua subjek memiliki kesamaan dalam dimensi ini pada salah satu indikator, yaitu mereka kurang bisa memahami potensi diri. Pada subjek MC, ia terlihat kesulitan menyebutkan apa yang menjadi kelebihan atau potensi dirinya. Ia hanya menyebutkan bahwa ia adalah orang yang mematuhi peraturan saat bekerja dan suka menjalin hubungan baik dan silahturahmi dengan orang lain. Sementara pada subjek AE, ia merasa bahwa ia tidak memiliki kelebihan apapun. Ia menyatakan bahwa ia sering mendapatkan pujian dari orang sekitarnya sebagai orang yang sabar dan rajin dalam bekerja, tapi ia tidak terlalu merasakan hal itu di dalam dirinya.

Selain perbedaan, kedua subjek tersebut juga memiliki persamaan pada indikator melihat kemajuan diri dan tingkah laku dari waktu ke waktu, terutama kemajuan diri yang mereka rasakan setelah pensiun. Setelah pensiun, subjek MC merasa lebih bisa memperdalam sisi spiritualnya. Ia juga merasa lebih punya banyak waktu untuk dihabiskan dengan keluarganya setelah pensiun. Sementara subjek AE menyatakan bahwa seiring umurnya yang sekarang ini ia merasa semakin dekat dengan Tuhan. Ia lebih banyak memanfaatkan masa pensiunnya untuk lebih mendekatkan diri kepada Tuhan.

Para subjek pria pensiunan PNS struktural yang menjadi tulang punggung keluarga dalam penelitian ini tampak menunjukkan kondisi psychological wellbeing yang tidak terlalu berbeda. Perbedaan yang tampak hanya pada dimensi "penerimaan diri", tepatnya pada indikator perasaan positif dan negatif mengenai diri masing-masing. Subjek MC yang memiliki latar belakang pendidikan tinggi dan jabatan terakhir sebagai Kepala Cabang Dinas Pendidikan merasa bangga atas pekerjaannya dan menganggap bahwa menjadi kepala dinas adalah salah satu kelebihannya. Sedangkan pada subjek AE, yang memiliki latar belakang pendidikan tidak terlalu tinggi dan jabatan 
terakhirnya adalah pesuruh yang merangkap sebagai staff administrasi, merasa kurang bangga dengan menyebut bahwa dirinya hanyalah pegawai rendahan saat masih bekerja.

Kondisi psychological well-being kedua subjek yang sama banyak ditemukan pada lima dimensi lain. Partisipan sama-sama berasal dari keluarga dengan kondisi ekonomi kurang baik, tetapi mereka kemudian mampu mengangkat kondisi ekonomi keluarganya dan sama-sama ingin agar keluarganya tidak mengalami hal serupa. Kedua partisipan adalah orang-orang yang peduli terhadap orang lain di sekitarnya. Partisipan MC mengutarakan bahwa di masa pensiunnya ini ia ingin mempergunakannya untuk lebih banyak membantu orang lain. Sementara partisipan $\mathrm{AE}$, ia menikmati pekerjaannya sebagai ketua RT meskipun tidak menerima gaji, karena merasa senang membantu dan lebih mudah jika ada tetangga yang membutuhkan bantuannya.

Kedua partisipan juga menunjukkan persamaan di dimensi otonomi. Kedua partisipan termasuk individu yang terbiasa mandiri sejak kecil sehingga mereka terbiasa untuk memutuskan sendiri segala sesuatu walaupun mereka memiliki beberapa orang yang dipercaya untuk diajak berdiskusi sebelum memutuskan suatu permasalahan. Partisipan MC mempercayakan hal tersebut pada istrinya, sedangkan partisipan $\mathrm{AE}$ mempercayakannya pada menantu ketiganya. Kedua partisipan juga menunjukkan persamaan di dimensi tujuan hidup. Mereka sama-sama ingin lebih mendekatkan diri kepada Tuhan setelah pensiun dan mempunyai keinginan dan harapan untuk kepentingan keluarga mereka. Partisipan MC ingin mempunyai satu rumah lagi untuk diberikan kepada anak bungsunya, sedangkan partisipan AE ingin memperluas usahanya sehingga kondisi finansial keluarganya akan semakin membaik.
Kedua partisipan mengaku tidak merasakan adanya gejolak psikologis dalam diri mereka setelah pensiun. Kedua partisipan menilai bahwa masa pensiun mereka cukup memuaskan karena bisa lebih banyak memiliki waktu luang yang bisa dimanfaatkan, seperti banyak waktu bersama keluarga, banyak waktu untuk memperbanyak ibadah, dan banyak waktu untuk menjalankan hobi mereka.

\section{SIMPULAN}

Dari hasil analisis didapatkan kesimpulan bahwa pensiun dari pekerjaan mereka sebagai PNS (Pegawai Negeri Sipil) struktural di usia dewasa madya bagi pria yang menjadi tulang punggung keluarga tidak berdampak buruk pada kondisi Psychological well-being dua partisipan penelitian ini. Mereka mampu menyesuaikan diri dan menerima keadaan mereka pascapensiun dengan melakukan kegiatan-kegiatan pengganti yang digunakan sebagai sumber pendukung finansial maupun sebagai pengisi waktu luang sekaligus menjalankan hobi mereka.

Peneliti menyimpulkan bahwa setidaknya terdapat 3 (tiga) faktor yang memengaruhi kondisi psychological wellbeing kedua partisipan yang positif, yaitu: sumber finansial yang memadai, ada kegiatan sosial, dan status pekerjaan sebelum pensiun.

Sumber Finansial. Kedua partisipan memiliki beberapa usaha yang mereka miliki dan persiapan sebelum mereka memasuki masa pensiun. Usaha-usaha inilah yang mereka andalkan untuk mengganti kekurangan finansial yang timbul. Hal ini sesuai dengan salah satu kondisi yang dapat memengaruhi penyesuaian terhadap masa pensiun seperti diungkapkan oleh Hurlock (1994), yaitu status ekonomi yang baik yang memungkinkan seseorang untuk hidup dengan nyaman dan menikmati hal-hal yang 
baik di masa pensiun.

Kegiatan Sosial. Kedua partisipan masih terlibat aktif dalam organisasi kemasyarakatan maupun yang berkaitan dengan hobi mereka. Hal ini sesuai dengan yang diungkapkan oleh Bull \& Aucoin, Cutler, dan Kline (dalam Hurlock, 1994) yang menyatakan bahwa partisipasi aktif dalam kelompok memberikan sumbangan besar terhadap kesejahteraan psikologis atau Psychological well-being dan meningkatkan kepuasan hidup yang diperoleh.

Status Pekerjaan Sebelumnya. Pada partisipan AE, jabatan terakhirnya sebelum pensiun adalah seorang pesuruh. Hal ini berarti bahwa ia menjalani sebuah pekerjaan dimana ia tidak memiliki bawahan, namun memiliki pimpinan. Hal ini menyebabkan ia tidak terlalu merasa kehilangan pekerjaan dan tidak mengalami gangguan psikologis seperti post-power syndrome saat pensiun. Pada akhirnya hal ini berpengaruh positif terhadap pembentukan sikap dan penyesuaian dirinya di masa pensiun.

Salah satu dimensi yang dimiliki oleh kedua partisipan yang terlihat paling positif adalah dimensi penerimaan diri. Kedua partisipan merasa menerima keadaan mereka setelah pensiun sebagai suatu siklus kehidupan yang harus mereka jalani. Kedua partisipan mampu memaknai kehidupan mereka sebagai sesuatu yang harus dijalani dan tidak ingin menyesali hal-hal yang telah mereka lalui. Mereka memandang pengalaman hidup mereka, seperti sulitnya ekonomi keluarga di masa kecil kedua partisipan, mereka sikapi sebagai suatu cara untuk menghindarkan anak-anak dan keluarganya dari keadaan sulit seperti yang pernah mereka rasakan. Hal ini yang akhirnya memengaruhi pola persiapan mereka sebelum pensiun dengan cara menyiapkan sumber finansial lain untuk menjamin kondisi ekonomi keluarga.

Kedua partisipan juga memiliki tujuan hidup yang sama setelah pensiun, yaitu untuk mendekatkan diri kepada Tuhan dan memperbanyak ibadah. Faktor religiusitas inilah yang belum dikupas oleh Ryff dalam penelitian-penelitiannya mengenai faktorfaktor yang berperan dalam kondisi psychological well-being individu. Keyakinan terhadap ajaran agama kedua partisipan untuk selalu menerima masa pensiun sebagai sebuah bagian dari kehidupan menyebabkan kedua partisipan memiliki kondisi Psychological Well-Being yang cukup baik saat menjalani masa pensiun.

\section{SARAN}

Hasil penelitian ini memberi informasi yang penting bagi mereka yang akan masuk masa pensiun dari pekerjaannya. Peneliti menyarankan bagi para calon pensiunan agar melakukan persiapan segala sesuatunya sebelum pensiun, baik secara psikologis, finansial, maupun aspek spiritual. Karena tanpa persiapan yang matang, masa pensiun akan berpengaruh kurang baik pada kondisi kesejahteraan psikologis (psychological wellbeing) mereka. Bagi para peneliti selanjutnya, hasil penelitian ini diharapkan bisa memberi informasi tentang psychological well-being dalam konteks yang khas, yakni PNS struktural dengan jumlah partisipan yang minim. Meski begitu, hasil penelitian ini bisa menjadi bahan perbandingan bagi penelitian selanjutnya yang mengambil topik yang sama dalam konteks yang lain dan jumlah partisipan yang berbeda.

Saran yang dapat diajukan mempertimbangkan hasil penelitian ini di antaranya berkenaan dengan kepentingan ilmiah. Para peneliti lain yang tertarik dengan masalah ini disarankan untuk mengkaji kembali masalah ini dengan jangkauan yang lebih luas, sehingga hasilnya dapat digeneralisasikan secara lebih luas lagi dengan melibatkan faktor-faktor yang lain, seperti tipe 
kepribadian, jenis kelamin, dan sebagainya.

\section{DAFTAR PUSTAKA}

Anggi, A. (2004). Stress dan Pensiun. (Online). http://jbptgunadarma-asrianggri-610bab1.pdf + stress + pensiun\&id\&gl $=\mathrm{id} \& \mathrm{ct}=\mathrm{c}$ lnk\&cd=2, Diakses pada tanggal 14 juni 2011.

Eliana, R. (2003). Konsep Diri Pensiunan. (Online) http://repository.usu. ac.id/bitstream/123456789/3632/1/psikolo gi-rika\%20eliana.pdf. Diakses pada tanggal 11 Januari 2011

Hendry, L. B. \& Kloep, M. (2002). Lifespan Development: Resources, Challenges and Risks. Oxford: Thompson Learning.

Hurlock, E. B. (1994). Psikologi Perkembangan: Suatu Pendekatan Sepanjang Rentang Kehidupan. (Alih bahasa: Istiwidayanti \& Soedjarwo). Edisi Kelima. Jakarta: Erlangga.

Latief, Ehsan. (2001). Retirement and Mental Health (Online). Http://search.ebscohost. com. Diakses pada tanggal 11 februari 2011

Moleong, L. J. (2006). Metode Penelitian Kualitatif. Bandung: PT. Remaja Rosda karya

Poerwandari, K (2001). Pendekatan Kualitatif untuk Penelitian Perilaku Manusia. Jakarta: Lembaga Pengembangan Sarana Pengukuran dan Pendidikan Psikologi (LPSP3) Fakultas Psikologi Universitas Indonesia.
Ryff, C. D. (1989). Happiness Is Everything, Or Is It? Explorations On The Meaning Of Psychological Well-Being. Journal of Personality And Social Psychology, (Online), 57 (6), 1069-1081.

Siegelman, C.K \& Rider, E.A (2006). Lifespan Human Development. California : Thompson Wadswort

Santrock, J. W. (2002). Perkembangan Masa Hidup. Jakarta: Erlangga.

Sutarto, T, J. \& Ismulcokro, C. (2008). Pensiun Bukan Akhir Dari Segalanya: Cara Cerdas Menyiasati Masa Pensiun. Jakarta: Gramedia.

Riawati, R. R. (2006). Gambaran Psychological Well Being Pada Wanita Dewasa Madya Yang Menjanda Akibat Suami Meninggal Dunia (Studi Kasus). Skripsi, tidak diterbitkan : Surabaya, Universitas Airlangga. 